Jpn. J. Pharm. Health Care Sci.

ノ - ト 30(6) 401-406 (2004)

\title{
救急用定数配置薬管理システムの評価と見直し作業の効果
}

\author{
田中 守*，山下梨沙子，守口淑秀，池川嘉郎，末丸克矢，荒木博陽 \\ 愛媛大学医学部附属病院薬剤部

\section{Evaluation of a Computer System for Managing Emergency Stocks of Medicine and Results of Reconsidering Their Selection}

\author{
Mamoru Tanaka*, Risako Yamashita, Toshihide Moriguchi, Yoshirou Ikegawa, \\ Katsuya Suemaru and Hiroaki Araki \\ Division of Pharmacy, Ehime University Hospital \\ $\left[\begin{array}{l}\text { Received October 30, } 2003 \\ \text { Accepted March 25, } 2004\end{array}\right]$
}

For the efficient management of stock medicines at our hospital, we developed a computer system in which expiration dates are recorded and used data produced by it to reconsider our selection of stock medicines.

We report on an evaluation of this system. The monitoring of expiration warning lists automatically generated by the computer system by our pharmacists prevented stock medicines from expiring before use. Further, a reconsideration of our stock medicines based on usage data in each ward produced a $25.0 \%$ decrease in the total number of medicines stocked and a $24.7 \%$ decrease in the overall cost of stock medicines. Thus, the computer management system enhanced safety for our stock medicines and a reconsideration of medicines stocked based on usage data enabled us to reduce ward costs.

Key words — stock medicine, computer-aided system, management system, expiration date

\section{緒言}

平成13年に国立大学医学部附属病院長会議常置委員会 が作成した「医療事故防止のための安全管理体制の確立 に向けて」1)の提言には, 病棟在庫医薬品の削減および 管理体制の適正化に関する指摘がなされている。この提 言には，薬剤の取り間違いや処方に基づかない与薬によ る医療事故防止，ならびに向精神薬や毒薬などの紛失事 件防止のための, 病棟, 外来, 中央診療部における在庫 医薬品 (以下, 配置薬と略す)の削減の必要性が盛り込ま れている。これに加えて, 医薬品の使用期限切れを減少 させることが医療資源の有効利用ならびに病院経営上も 大変重要となる。一方，使用期限が短くなった配置薬を 回収して薬剤部の調剤用在庫医薬品 (以下, 一般医薬品 と略す)として有効に利用するには, 配置医薬品数の適 正化と交換時期の設定が重要となる。薬剤師が医療チー ムの一員として配置薬管理の適正化に貢献するために は, 冷所保存 - 遮光保存などの保管法や取り間違え防止 のための配置法などを助言することに加え, 配置薬を直
接, 薬剂師が確認することが重要である ${ }^{1-3)}$.

愛媛大学医学部附属病院 (以下, 当院と略す)では緊急 医薬品に限定して病棟, 外来, 中央診療部に救急用定数 配置薬を常備している，当院薬剤部では，配置薬の削減 と管理体制の適正化を目的に，長期にわたって配置薬品 管理業務の改善を行ってきた.まず, 1999年 3 月よりデー タベースソフト (Microsoft Access $\left.97^{\circledR}\right)$ を使用して配置薬 管理システムを構築した。 そして, 配置薬情報の一元管 理を開始し，管理業務の効率化を図った。2002年 9 月か らは薬剂師が病棟に出向いて配置薬の確認を行った。さ らに，2003年 3 月には配置薬の見直し作業を行い, 配置 薬の削減を行った，本論文では，当院の配置薬管理支援 システムを使用した配置薬管理体制の評価と配置薬の見 直し効果について報告する。

\section{方法}

\section{1. 注射オーダによる配置薬の流れ}

病棟で配置薬を使用した場合, 医師は注射オーダリン グシステムで『配置薬実施済み』の注射せんを発行する. 
この薬札には, 注射薬指示内容, 貯法に加えて, 『定数 配置薬に返却してください』というコメントが印字さ れ，配置薬を使用したことがわかるようになっている。 配置薬実施済みのオーダに対して, 薬剤部では在庫の中 で使用期限の最も長い医薬品を払い出す。病棟では, 注 射薬札の『定数配置薬に返却してください』のコメント を確認し，配置薬を配置薬カートに補充する(図 1 ).

\section{2. 配置薬管理システムの概要}

配置薬管理システムは，Microsoft Access $97^{\circledR}$ 使用し て作成した．各機能はメニュー画面で簡単に操作できる ように配置薬の数量, 使用期限の登録・変更,削除処理, 新規薬剂の追加，リスト印刷，部署別検索などの機能を 持たせた(図 2)。薬品マス夕は，薬剤コード，薬品名， 保存条件, 薬価, 薬效分類からなる。配置薬デー夕は薬 剂コード, 薬品名, 数量, 部署, 使用期限, 更新月日か ら構成し, 各薬品マス夕と配置薬デー夕を連携させた。 特に，使用期限のチェック機能に関しては，パソコン起 動時に 3 力月後が使用期限となる医薬品を自動的に抽出 し, 配置部署別に使用期限チェックシート (図 3)が注射 室の端末パソコンから月に 1 回自動的に薬剤部に印刷さ
れるように設定した。

\section{3. 使用期限の管理方法}

1999年 3 月より配置薬管理システムを使用した配置薬 情報の一元管理を開始した。当初は, 薬剤部より各部署 に送付した使用期限チェックシート（図 3 )を基に, 看護 師が配置薬の点検と交換を行い, 薬剂部は補充した配置 薬の使用期限を登録するのみであった。2002年 9 月から は，病棟薬剂師が使用期限チェックシートと配置薬一覧 リス卜 (図 4 )を用いて, 配置薬の保管場所での使用期限 の確認，回収㧍よび補充を行った(図 1 )。今回は，薬剤 師による配置薬の直接管理を開始した2002年10月以前と それ以降に病棟で発生した配置薬の使用期限切れ件数な らびに使用期限チェックによる配置薬回収件数を 6 カ月 毎に調べた.

\section{4. 配置薬管理システムのメンテナンス}

使用期限, 数量の変更㧍上び配置薬の新規追加は, 薬 品名の選択にリストボックスを使用してメンテナンスが 容易にできるように工夫した配置薬メンテナンス画面か ら行った(図 5 )。また，配置薬管理システムのメンテナ
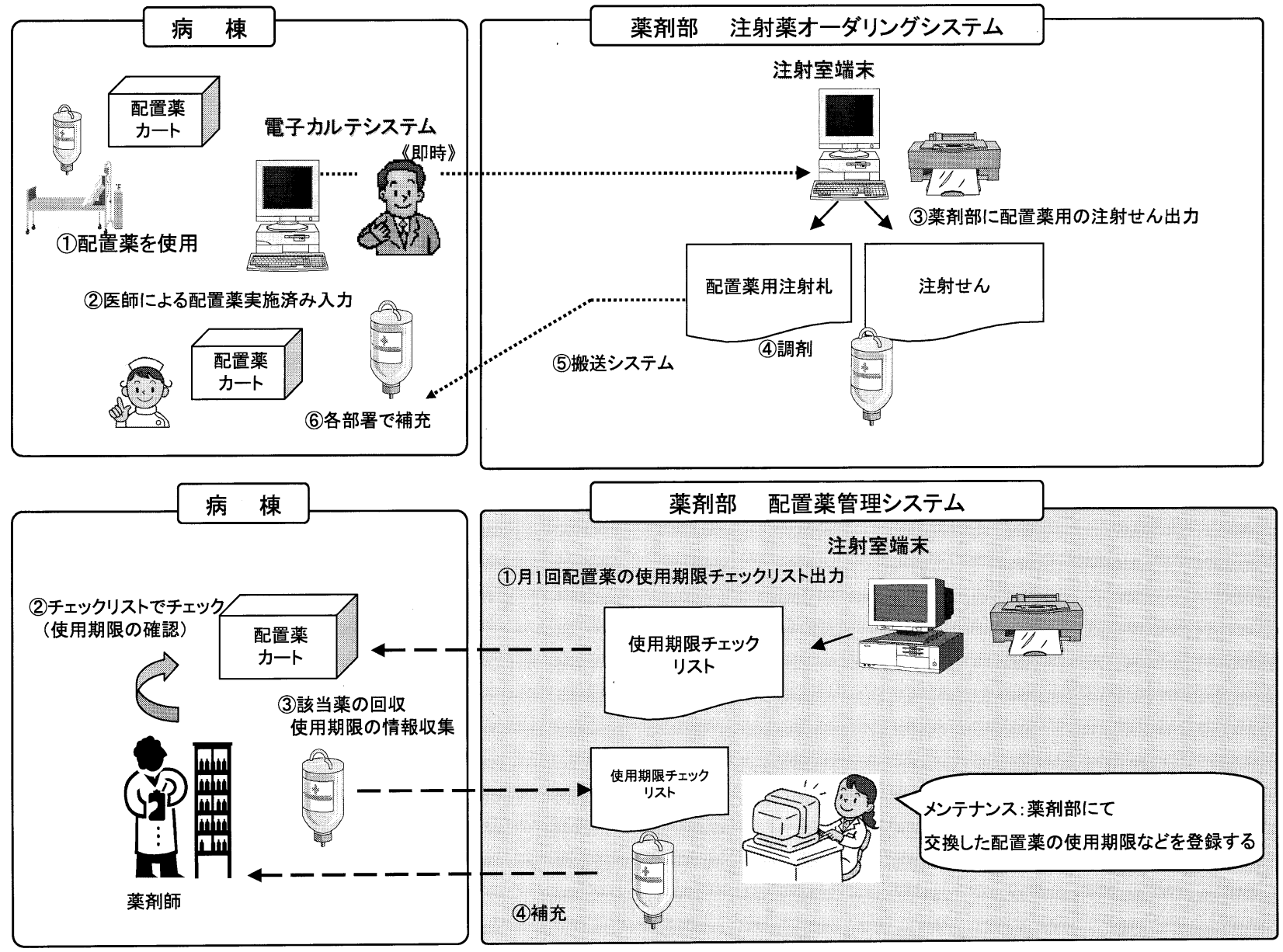

図 1. 配置薬の流れ図(オーダリングシステムと配置薬管理システム) 
救急用定数配置薬管理システム

管理機能

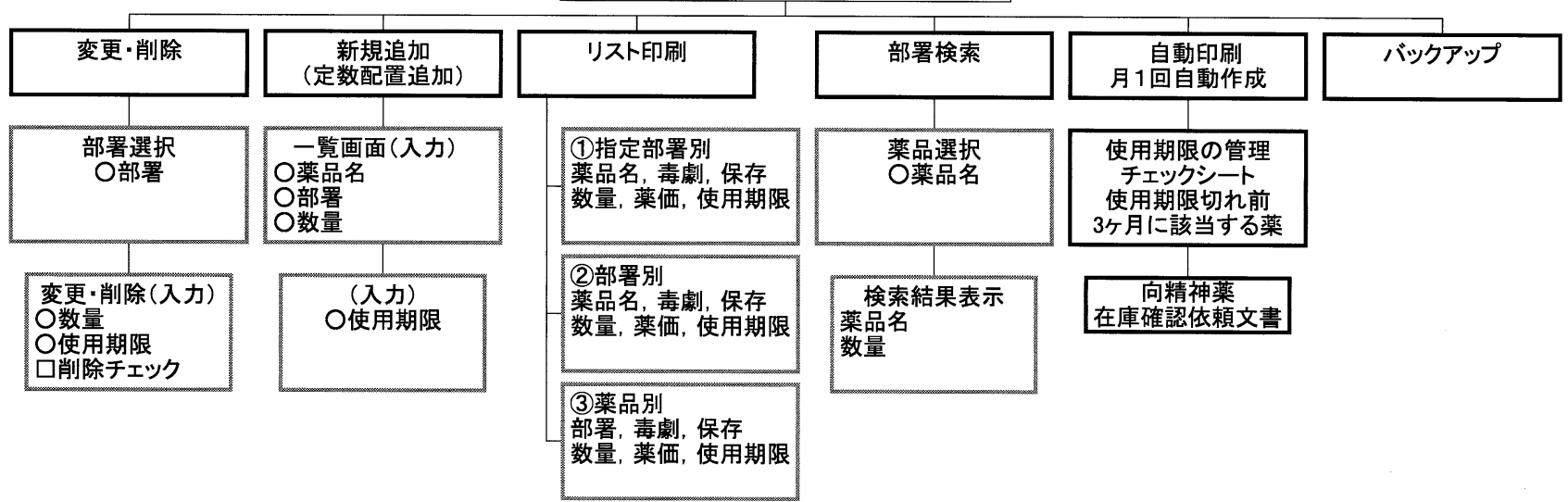

図 2. 救急用定数配置薬管理システムの各機能

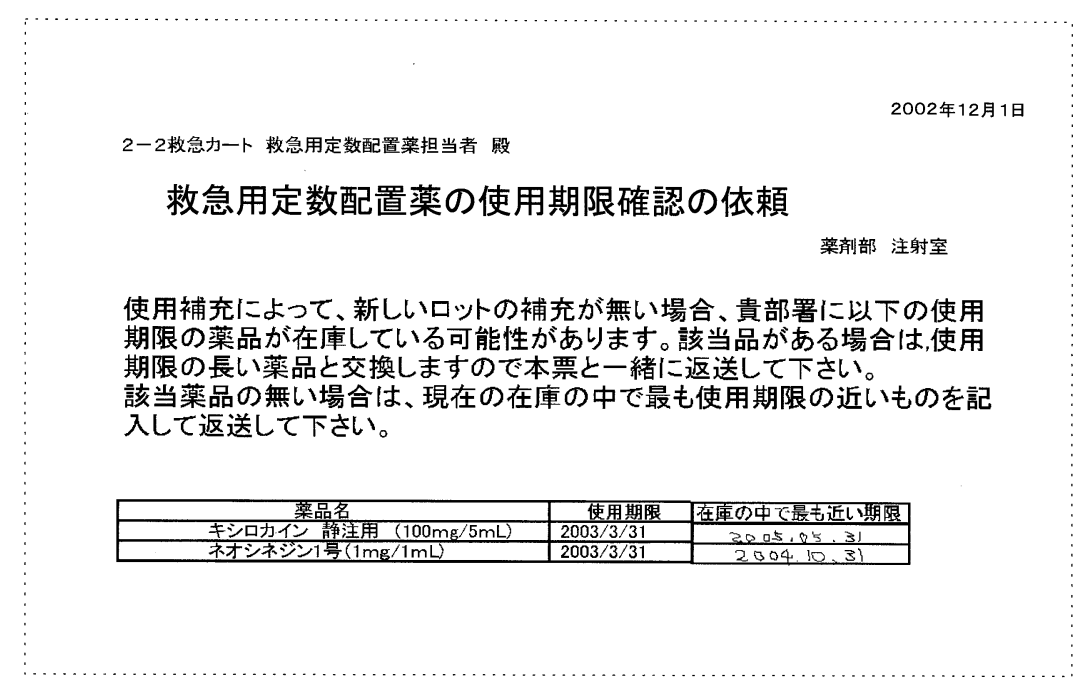

図 3. 使用期限チェックシート

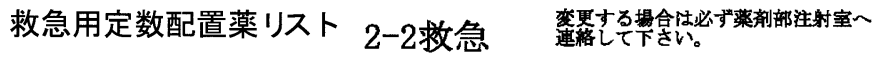

\begin{tabular}{|c|c|c|c|c|c|}
\hline 薬品名 & 分類 & 数量 & 保存条件 & 薬価 & 使用期限 \\
\hline アトロピン $(0.5 \mathrm{mg} / 1 \mathrm{~m} \ell)$ & 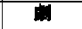 & 3 & 室温・遮光 & 97.00 & $2004 / 09$ \\
\hline エフェドリン $(40 \mathrm{mg} / 1 \mathrm{ml})$ & 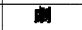 & 2 & 宝祖・遮光 & 97.00 & $2006 / 01$ \\
\hline エホチール $(10 \mathrm{mg} / 1 \mathrm{m \ell})$ & 离 & 3 & 宝沮・遮光 & 64.00 & $2004 / 01$ \\
\hline カルチコール $(850 \mathrm{mg} / 10 \mathrm{m \ell})$ & F通 & 2 & 室温 & 80.00 & $2003 / 09$ \\
\hline キシロカイン静 $(100 \mathrm{mg} / 5 \mathrm{ml})$ & - & 2 & 室沮 & 97.00 & $2003 / 03$ \\
\hline セイショク $(20 \mathrm{ml})$ & Fi⿺ & 5 & 室沮 & 64.00 & $2005 / 11$ \\
\hline セイショク & F通 & 1 & 室温 & 135.00 & $2003 / 12$ \\
\hline 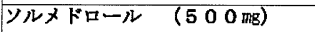 & *洋 & 2 & 室沮 & $4,870,00$ & $2003 / 06$ \\
\hline F゙ルミカム $(10 \mathrm{mg} / 2 \mathrm{ml})$ & 间了一音 & 2 & 室沮 & 200.00 & $2006 / 02$ \\
\hline ネオシネジン 1 量 $(1 \mathrm{mg} / 1 \mathrm{ml})$ & thes & 2 & 室温・遮光 & 64.00 & $2003 / 03$ \\
\hline ノルアドレナリン $(1 \mathrm{mg} / 1 \mathrm{ml})$ & 尚 & 2 & 室沮・遮光 & 97.00 & $2004 / 02$ \\
\hline 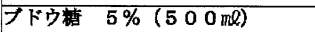 & *道 & 1 & 室沮 & 141.00 & $2004 / 02$ \\
\hline プロタノールL $(0.2 \mathrm{mg} / 1 \mathrm{ml})$ & 車 & 2 & 室温・遮光 & 289.00 & $2003 / 07$ \\
\hline ボスミン (1 mb/ $1 \mathrm{ml})$ & 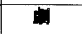 & 3 & 害沮・遮光 & 97.00 & $2003 / 06$ \\
\hline 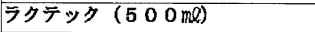 & 兽通 & 1 & 室沮 & 147.00 & $2004 / 03$ \\
\hline
\end{tabular}




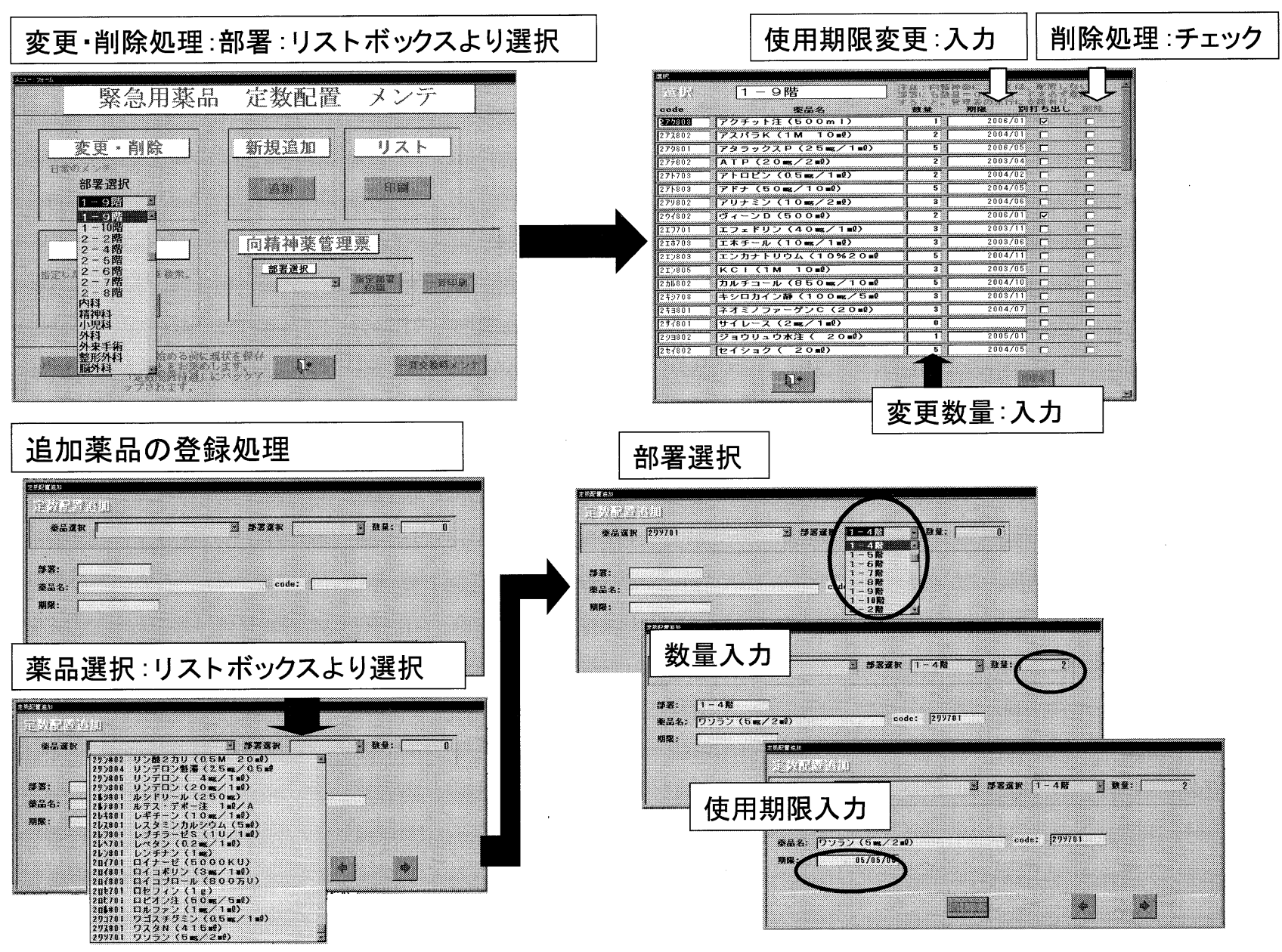

図 5.配置薬管理システムのメンテナンスの流れ

ンスは注射室の部員が行うこととし，使用期限チェック シートに基づいた変更事項の更新は 1 カ月に 1 回まとめ て登録することとしている。

\section{5. 向精神薬管理業務}

当院では向精神薬を配置薬として常備する場合，向精 神薬管理施用代表者が每月 1 日に各診療科の向精神薬管 理票を薬剤部へ提出する報告体制を取っている。今回， われわれが構築した配置薬管理システムには，向精神薬 管理業務を効率化するために，向精神薬管理票(図 6)が 自動印刷されるようにした。

\section{6. 配置薬の見直し作業}

配置薬の適正化を目的として，各診療科・診療部にお ける配置薬の見直し作業を2003年 3 月に実施した。この 見直し作業では，各診療科の実情に応じて医師，看護師 が十分検討できるように，各診療科の注射処方データか ら薬剂部が立案した適正配置薬数量と，1 カ月間の使用 実績を各部署に提供した。さらに，配置薬の総合計数と 3 力月間の処方データから, 廃衰の可能性がある薬剤り
ストを作成し，参考資料として添付した。今回，配置薬 の見直し作業の評価は, 配置薬の品目数, 本数㧍よび総 薬価の変化を調べることにより行った。

\section{7. 交換時期の設定とその評価}

配置薬管理システムでは, 使用期限の 3 カ月前に使用 期限チェックシートが自動印刷できるように設定した。 この交換時期の設定を検証する目的で, 配置薬の総数が 3 カ月間で一般医薬品として処方可能な割合 ( 3 力月回 転指数： 3 力月間の一般医薬品としての使用数 $\div$ 配置薬 の総数 $\times 100)$ を算出した。すなわち, 配置薬の 3 力月回 転指数が 100 以上であれば 3 力月前の交換時期の設定で その配置薬のすべてが一般医薬品として使用可能と推察 され，使用期限切れを発生する可能性がないと考えられ る. 今回の検証では， 3 力月回転指数を $0,0 \sim 10,10$ 50，50 100，100以上の 5 段階に分類し，使用期限の 3 カ月前という交換時期の妥当性を検討した。さらに, 配 置薬の見直し作業の効果を評価するために, 作業前後 でデットストックのリスクとなり得る配置薬の数量を比 較した。 


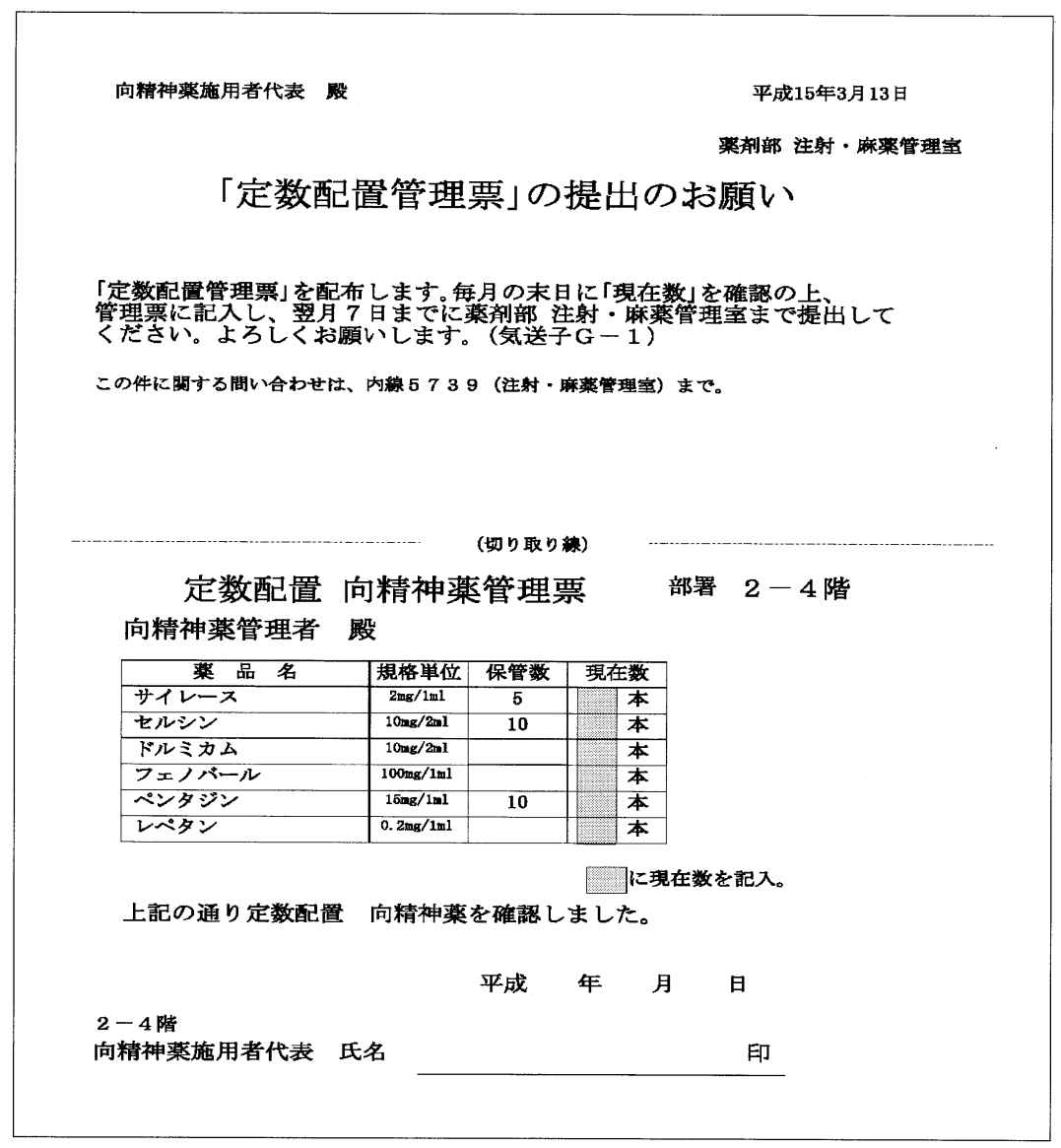

図 6. 定数配置向精神薬管理票

\section{結果}

\section{1. 配置薬管理システムを使用した配置薬管理}

薬剂部が配置薬管理システムを用いて調査した使用期 限・数量などの管理情報を診療科・診療部へ提供し，看 護師が点検・交換を実施していた期間(2001年10月〜 2002年 3 月, 2002年 4 月～2002年 9 月)では,それぞれ, 6 本，13本の使用期限切れ報告があった(表 1 ). しかし， 薬剂師が病棟に出向き使用期限チェックシートと一覧リ スト(図 4 )を用いて配置薬の管理・点検を開始した2002 年10月以降は，使用期限切れ報告はまったくなかった。

\section{2. 配置薬見直し作業の評価}

配置薬の見直し前は，配置部署は40部署，保管場所は 51力所, 医薬品の種類は242品目, 総本数は5612本であっ た。しかし，見直し作業によって，配置部署(38部署) と 保管場所 (51力所) はほとんど変わらなかったものの，医 薬品の種類は233品目 $(-3.7 \%)$, 総本量は4211本 $(-$ $25.0 \%) に$ 減少した。さらに，薬価換算の総額は，約 272 万円から約205万円へと約 67 万 $(-24.7 \%)$ の低下と なった。

\section{3. 管理システムのメンテナンスの評価}

管理システムで使用期限の更新の必要性が認められた 件数は2002年 4 月～2002年 9 月，2002年10月～2003年 3 月の半年間でそれぞれ278件，220件であった(表 2$). す$ なわち，使用期限の更新が必要な配置薬は月平均で約 41.5 件であるが，月 1 回メンテナンス画面(図 5 )からま とめて行う使用期限の更新作業時間は約20分であった。 また，薬品マス夕は，薬品発注システムのマスタをコン パイルし必要な部分のみを利用することにしたため容易 に作成可能であった。しかし，システム開始時には，薬

表 1．配置薬の使用期限切れ報告状況

\begin{tabular}{|c|c|c|}
\hline 期間 & 部署数 & 廃棄数量 \\
\hline $\mathbf{2 0 0 2 . 1 0 ~} 2003.3$ & $\mathbf{0}$ & $\mathbf{0}$ \\
\hline $2002.4 \sim 2002.9$ & 8 & 13 \\
\hline $2001.10 \sim 2002.3$ & 3 & 6 \\
\hline
\end{tabular}

\section{表 2. 配置薬の交換件数と使用期限の更新件数}

\begin{tabular}{|c|c|c|c|}
\hline 期間 & 部署数 & $\begin{array}{c}\text { 使用期限の } \\
\text { 更新件数 }\end{array}$ & $\begin{array}{c}\text { 配置薬を交 } \\
\text { 換した件数 }\end{array}$ \\
\hline $2002.10 \sim 2003.3$ & 120 & 220 & 101 \\
\hline $2002.4 \sim 2002.9$ & 134 & 278 & 121 \\
\hline
\end{tabular}


表 3. 見直し作業による回転指数の変化

\begin{tabular}{|c|rr|rr|}
\hline 3力月回転指数 & \multicolumn{1}{|l|}{ 見直し前 $(\%)$} & \multicolumn{2}{|l|}{ 見直し後 $(\%)$} \\
\hline 0 & 15 & $(0.3)$ & 15 & $(0.4)$ \\
\hline $0 \sim 10$ & 88 & $(1.6)$ & 0 & $(0)$ \\
\hline $10 \sim 50$ & 66 & $(1.1)$ & 24 & $(0.6)$ \\
\hline $50 \sim 100$ & 69 & $(1.2)$ & 47 & $(1.0)$ \\
\hline 100 以上 & $5374(95.8)$ & $4125(98.0)$ \\
\hline 総配置薬数 & 5612 & \multicolumn{2}{|c|}{4211} \\
\hline
\end{tabular}

品, 数量, 使用期限の登録に時間を要した。以上のこと から，当初の登録には労力を要するものの，配置管理シ ステムのメンテナンス自体は比較的容易であると考えら れる。

\section{4. 交換時期の設定の評価}

3 力月回転指数, すなわち使用期限切れ 3 力月前に交 換時期を設定した場合に，すべての配置薬が一般医薬品 として使用できる割合を指標にして，配置薬の見直し作 業の効果を評価した(表 3 ). 3 力月回転指数が100以上 の配置薬数は，見直し作業前で全体の薬品数の95.8\%で あったが，見直し作業後は $98.0 \%$ に改善した. 3 力月間 使用実績のない配置薬 ( 3 力月回転指数 0$)$ の割合 は，0.3\%から0.4\%とほとんど変化がなかった。

\section{考察}

著者らが構築した市販データベースソフトを使用した 配置薬管理支援システムにより，薬剤部における配置薬 の一元管理, すなわち, 数量管理, 配置薬リス卜作成, 使用期限が近い医薬品の抽出, 使用期限チェックシート および向精神薬管理票の印刷など煩雑な準備作業が効率 化された。また，使用期限などの更新作業は，月に 1 回 20分程度で終了することから，配置薬管理システムのメ ンテナンスの負担が少ないと思われる．さらに，この管 理システムから自動的に出力されたデー夕を基に, 配置 薬の確認を薬剤師が直接行うことで使用期限のチェック 漏れが防止された。

今回の見直し作業により, 配置薬の総本数は1401本 $(-$ $25 \%)$ 減少し，薬価換算では約 67 万の減額となった。 さらに，3 カ月回転指数という配置薬が一般医薬品とし て使用できる割合で評価した場合も，顕著な改善が認め られ，見直し作業の効果が窺われた。この病棟配置薬の 見直し作業を行うにあたり，薬剂部から各部署に提供し た使用実績情報が医師や看護師が配置薬の適正数量を決
定するうえで役立ったと考えられる。

当院では以前より配置薬の交換時期を使用期限切れの 3 力月前に設定している。 今回，この交換時期を評価し た結果，配置薬の見直し後では 3 力月回転指数が 100 以 上の配置薬の割合は $98.0 \%$ あった。したがって，当院 の場合，使用期限 3 力月前に回収する交換時期の設定は 妥当であると考えられた。しかし，配置薬の見直し後に おいても 3 力月回転指数が100未満の医薬品は 9 品目あ り，デットストックの可能性がある．実際，長期間動き のない亜硝酸アミル，塩酸ドキサプラム，ニトロプルシ ドナトリウム，プリドキシム・ヨウ化メチルなどの薬物 拮抗剤や薬物中毒治療剤などの回転指数は低く，極めて 非流動的ではある。しかし，これらの緊急性の高い稀用 医薬品を医療現場に常備することは不可欠であり ${ }^{4)}$, 緊 急性を持つ稀用医薬品は回転指数によって常備の可否を 決定することはできないと考えられる，さらに，医薬品 の年間の消費動向は，一定ではなく，必ずしも 3 力月回転 指数が100以上の配置薬であっても，回収後 3 力月で消 費されるとは限らない.したがって, 交換時期の設定は, 新薬の登場，保険制度の改正によって変動することが考 えられ，定期的に回転指数の算出や配置薬の見直し作業 を行うことが重要である.

以上のように，データベースソフトを利用した配置薬 の一元管理システムの構築，薬剤師による配置薬の管 理, 向精神薬の文書での在庫確認および配置薬の見直し 作業によって, 配置薬の使用期限切れが減少し, 医薬品 紛失防止ならびに使用期限切れ配置薬の使用による医療 事故防止や医療資源の有効利用に貢献できたと考えられ る.

\section{引用文献}

1）医療事故防止方策の策定に関する作業部会著，医療 事故防止のための安全管理体制の確立に向けて〔提 言], 国立大学医学部附属病院長会議編, 日総研出 版，東京，2001, pp.100-101.

2) 病棟におけるリスクマネジメントへの薬剤師の関 与，佐藤智昭，豊田倫子，松香直行，二神幸次郎， 岡本輝子, 荒木博陽, 五味田裕, 仲倉俊恵, 大月洋, 日病薬誌，37, 31-34(2001).

3) 毒薬・向精神薬の管理・運用システムの検討, 医薬 ジャーナル，38, 238-244(2002).

4) 田中寛, 必須医薬品の供給とその管理, 臨床と薬物 治療，22, 184-191(2003). 